Marine Pollution Bulletin

Vol. 50, Issue 12, December 2005, Pages 1719-1723

http://dx.doi.org/10.1016/j.marpolbul.2005.09.009

(c) 2005 Elsevier Ltd All rights reserved
Archimer, archive institutionnelle de l'Ifremer http://www.ifremer.fr/docelec/

\title{
Distribution of silver in mussels and oysters along the French coasts: Data from the national monitoring program
}

\author{
Jean-François Chiffoleau* Dominique Auger, Nathalie Roux, \\ Emmanuelle Rozuel and Anne Santini
}

IFREMER Centre de Nantes, Departement DCN/BE, BP 21105, 44311 Nantes Cedex 3, France

*: Corresponding author : ㄷchiffo@ifremer.fr

Keywords : Monitoring, silver, coastal water, France, mollusks

Distribution and behavior of many trace elements in the aquatic environment has been well characterized, but little is known about silver $(\mathrm{Ag})$ concentrations in coastal waters, even though this element ranks among the most toxic to marine invertebrates (Calabrese et al., 1977 ; Fisher and Hook, 1997 ; Webb and Wood, 1998). Studies conducted by Flegal et al. (1995), River-Duarte et al. (1999), and Ndung'u et al. (2001), provided the first valuable data on Ag distribution in the oceanic environment, indicating that this element is found in very low concentrations in the dissolved phase. However, although silver concentrations in coastal waters do not reach the nanomolar range (Smith and Flegal, 1993 ; Squire et al., 2002), formation of a stable chloro complex enhances bioavailability and toxicity to biota (Luoma et al., 1995). Experimental studies have shown that Ag is toxic to some living organisms at environmentally realistic levels (Bryan and Langston, 1992). Silver found in the aquatic environment mainly originates in effluents from sewage treatment plants (Rozan and Hunter, 2001). Silver can therefore be used as a tracer of wastewater discharges in coastal waters (Martin et al., 1988 ; Sañudo-Wilhelmy and Flegal, 1992), for instance through the use of sentinel organisms, which concentrate bioavailable contaminants in their tissues (Stephenson and Leonard, 1994 ; Jiann and Presley, 1997 ; Riedel et al., 1998 ; Muñoz-Barbosa et al., 2000).

This study concerns biological monitoring as a means of providing a synoptic view of silver contamination in French coastal waters. The National Network for the Observation of Marine Environment Quality (RNO, the French Mussel-Watch) which has been regularly measuring concentrations of various chemical contaminants in oyster and mussel tissues for 25 years (Claisse, 1989), has been monitoring silver levels since 2003. This valuable database including data collected at 80 sampling sites distributed along the French coasts (Fig. 1), is used as a reference to provide the spatial distribution of a given contaminant (Chiffoleau and Bonneau, 1994), identify trends of contamination/decontamination (Chiffoleau et al., 2001), and detect peak concentrations due to accidental events (Chiffoleau et al., 2004). Mussels (Mytilus edulis and Mytilus galloprovincialis) and oysters (Crassostrea gigas) are collected twice a year in February and November. Sample collection (size of samples, size of animals) and treatment (cleaning, depuration, removal of soft parts from the shells, draining, homogenization, and freeze-drying) are performed according to the OSPAR Convention guidelines and the method described by Claisse (1989). 
Aliquots of dried samples $(200 \mathrm{mg})$ were mineralized by nitric acid $\left(\mathrm{HNO}_{3}\right)$ at $90^{\circ} \mathrm{C}$ and atmospheric pressure (a routine procedure also used for other trace metals) and Ag levels were analyzed by graphite furnace atomic absorption spectrometry (AA800, Varian) using the Zeeman background correction for non-specific absorption. Although results with certified reference materials seemed satisfactory (Table 1), another analytical procedure described by Daskalakis et al. (1997), which uses a mixture of $\mathrm{HNO}_{3}$ and $\mathrm{HCl}$, instead of $\mathrm{HNO}_{3}$ alone, was tested. In agreement with these authors, but only in the case where samples contained high levels of $\mathrm{Ag}$, results obtained with the two methods significantly differed (Table 1). Martoja et al. (1988) showed that in oysters (Crassostrea gigas) experimentally contaminated with $\mathrm{Ag}$, most of this metal is sequestered as sulfides in amoebocytes and basement membranes. The poor solubility of $\mathrm{Ag}_{2} \mathrm{~S}$ in $\mathrm{HNO}_{3}$ may account for the fact that different results were obtained with these two analytical procedures.. The procedure using the mixture of $\mathrm{HNO}_{3}$ and $\mathrm{HCl}$ described by Daskalakis et al. (1997) was therefore selected. These findings show that the use of certified standards with contaminant levels that are very different from that of samples, increases the risk of validating an analytical procedure that is inadequate for this type of monitoring. Average concentrations presented in this study were determined based on the analysis of 3 samples which were respectively collected in February and November 2003, and February 2004.

Ag concentrations (Fig. 2) ranged from 0.02 to $4.4 \mu \mathrm{g} \mathrm{g}^{-1}$ based on dry weight (d.w.) in mussels, and from 1.1 to $65 \mu \mathrm{g} \mathrm{g}{ }^{-1} \mathrm{~d}$.w. in oysters. As suggested by Daskalakis et al. (1997) and O' Connor (2002), who were concerned with the American Mussel-Watch program, such discrepancies between concentrations found in mussels and oysters may be attributable to biological factors inherent to the species (e.g., the bioaccumulation factor) as well as differences in exposure to the contaminant. This is illustrated by data collected at sampling sites 20, 21, and 22 located along the Northern coast of Brittany, where mussels and oysters live in similar environmental conditions. In this area, $\mathrm{Ag}$

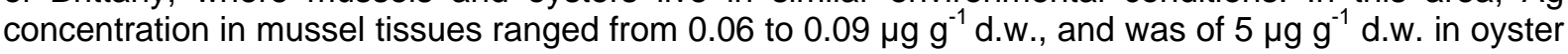
tissues. This suggests that oysters accumulate 50 to 100 times as much Ag than mussels. Experimental contaminations should be carried out in order to assess this ratio more precisely. Consequently, we avoided comparing sampling sites monitored with mussels with those monitored with oysters. By differentiating in Fig. 2 the concentration scales for mussels and for oysters (a factor of 50 was selected between the two Y-axis), we tried to obtain an instant image of silver contamination along the French coasts.

The lowest $\mathrm{Ag}$ concentrations measured in mussels were below the detection limit of the method routinely used by the RNO $\left(0.02 \mu \mathrm{g} \mathrm{g}^{-1} \mathrm{~d}\right.$.w.). Extensive analyses revealed Ag concentrations of approximately $0.014 \mu \mathrm{g} \mathrm{g}^{-1} \mathrm{~d}$.w. in mussels collected in the Thau lagoon (sampling sites 66 and 67). These concentrations are of the same order of magnitude as the lowest concentrations reported by Muñoz-Barbosa et al. (2000) in Mytilus californianus along the coast of Baja California. In the present study, the lowest Ag concentrations measured in oysters were around $1.1 \mu \mathrm{g} \mathrm{g}{ }^{-1} \mathrm{~d}$.w.. Presley et al. (1990), on the other hand, reported minimum concentrations of $0.2 \mu \mathrm{g} \mathrm{g}{ }^{-1} \mathrm{~d}$.w. in Crassostrea virginica from Tampa Bay, Florida. Our findings may therefore be reflective of a chronic contamination of French coastal waters. According to our results, the least contaminated areas in France were the Mediterranean coast (sampling sites 62 to 80) and Northern Brittany (sampling sites 14 to 24).

Figure 2 shows two areas contaminated with silver : the plume of the Seine River (sampling sites 6 to 9) and the Gironde estuary (sampling sites 52 to 54). According to the RNO, these two areas have been contaminated with other trace metals for a prolonged period (Claisse, 1989). Ag concentrations measured in these areas are very high compared to the lowest levels observed in France ( $\mathrm{max} / \mathrm{min}>200$ in mussels; $\mathrm{max} / \mathrm{min}=60$ in oysters). In mussels, however, these levels are relatively far from the highest concentrations reported by Daskalakis et al. (1997) in Mytilus californianus (34 $\mathrm{g} \mathrm{g} \mathrm{g}^{-1}$ d.w. at Point Loma, California). Silver mainly originates from urban effluents (Rozan and Hunter, 2001); however, as the sites affected by this Ag contamination are located in the estuarine plumes of two of the largest French rivers and consequently relatively far from potential continental Ag sources, these effluents may be highly diluted when they reach these downstream sites. This clearly indicates the significant availability of silver in saline water. Surprisingly, we did not observe peak concentrations at the mouth of the other two largest rivers of France, the Loire and the Rhone. Finally, this study shows that silver found in the plumes of rivers can be transported far from the point of discharge. A silver concentration gradient is thus observed in mussels from the north of France as far as sampling site 1, located nearly $300 \mathrm{~km}$ away from the Seine estuary, where concentrations reach $0.15 \mu \mathrm{g} \mathrm{g}^{-1}$ d.w., i.e. 10 times those observed in Northern Brittany. A gradient was also observed on the Atlantic coast, north of sampling site 54, located in the estuary of the 
Gironde. Concentrations ranging from 5 to $10 \mu \mathrm{g} \mathrm{g}^{-1} \mathrm{~d}$.w. were thus observed in oysters as far as sampling site 42. A similar gradient has been reported by Muñoz-Barbosa et al. (2000) along the coast of Baja California. This study shows that continental sources of silver, although located far away from the coastline, can extensively contaminate coastal waters and affect large areas. 


\section{References}

Bryan, G.W., Langston, W.J., 1992. Bioavailability, accumulation and effects of heavy metals in sediments with special reference to United Kingdom estuaries: a review. Environmental Pollution 76, 89-131.

Calabrese, A., Thurberg, F.P., Gould, E., 1977. Effects of cadmium, mercury and silver on marine animals. Marine Fisheries Review 39, 5-11.

Chiffoleau, J.-F., Bonneau C., 1994. Chromium content in French Coastal mussels and oysters. Marine Pollution Bulletin 28 (7), 458-460.

Chiffoleau, J.-F., Auger, D., Chartier, E., Michel, P., Truquet, I., Ficht, A., Gonzalez, J.-L., Romaña, L.A., 2001. Spatiotemporal changes in cadmium contamination in the Seine estuary (France). Estuaries 24 (6B), 1029-1040.

Chiffoleau, J.-F., Chauvaud, L., Amouroux, D., Barats, A., Dufour, A., Pécheyran, C., Roux, N., 2004. Nickel and vanadium contamination of benthic invertebrates following the "Erika" wreck. Aquatic Living Resources 17, 273-280.

Claisse, D., 1989. Chemical contamination of French coast. The results of a ten years mussel-watch. Marine Pollution Bulletin 20(10), 523-528

Daskalakis, K.D., O'Connor, T.P., Crecelius, E.A., 1997. Evaluation of digestion procedures for determining silver in mussels and oysters. Environmental Science and Technology 31, 23032306.

Fisher, N.S., Hook, S.E., 1997. Silver accumulation and toxicity in marine and freshwater zooplankton. In : Andren, A.W., Bober, T.W. (Eds.). Argentum: Proceedings of the 5th International Conference on the Transport, Fate and Effects of Silver in the Environment. University of Wisconsin, Sea Grant, pp. 265-274.

Flegal, A.R., Sañudo-Wilhelmy, S.A., Scelfo, G.M., 1995. Silver in the eastern Atlantic Ocean. Marine Chemistry $49: 315-320$.

Jiann, K.-T., Presley, B.J., 1997. Variations in trace metal concentrations in american oysters (Crassostrea virginica) collected from Galveston Bay, Texas. Estuaries 20(4), 710-724.

Luoma, S.N., Ho, Y.B., Bryan, G.W., 1995. Fate, bioavailability and toxicity of silver in estuarine environments. Marine Pollution Bulletin 31, 44-54.

Martin, M., Stephenson, M.D., Smith, D.R., Guttierrez-Galindo, E.A., Munoz, G.F., 1988. Use of silver as a tracer of domestic wastewater discharge. Marine Pollution Bulletin 19, 512-520.

Martoja, R., Ballan-Dufrançais, C., Jeantet, A.-Y., Gouzerh, P., Amiard, J.-C., Amiard-Triquet, C., Berthet, B., Baud, J.-P., 1988. Effets chimiques et cytologiques de la contamination expérimentale de l'huître Crassostrea gigas Thunberg par l'argent administré sous forme dissoute et par voie alimentaire. Canadian Journal of Fisheries and Aquatic Sciences 45(10), 1827-1841.

Muñoz-Barbosa, A., Guttierrez-Galindo, E.A., Flores-Muñoz, G., 2000. Mytilus californianus as an indicator of heavy metals on the northwest coast of Baja California, Mexico. Marine Environmental Research 49, 123-144.

Ndung'u, K., Thomas, M.A., Flegal, A.R., 2001. Silver in the western equatorial and South Atlantic Ocean. Deep-Sea Research II 48, 2933-2945.

O'Connor, T.P., 2002. National distribution of chemical concentrations in mussels and oysters in the USA. Marine Environmental Research 53, 117-143. 
Presley, B.J., Taylor, R.J., Boothe, P.N., 1990. Trace metals in Gulf of Mexico oysters. The Science of the Total Environment 97/98, 551-593.

Riedel, G.F., Abbe, G.R., Sanders, J.G., 1998. Temporal and spatial variations of trace metal concentrations in oysters from the Patuxent River, Maryland. Estuaries 21(3), 423-434.

River-Duarte, I., Flegal, A.R., Sañudo-Wilhelmy, S.A., Véron, A.J., 1999. Silver in the far North Atlantic Ocean. Deep-Sea Research II 46, 979-990.

Rozan, T.F., Hunter, K.S., 2001. Effects of discharge on silver loading and transport in the Quinnipiac River, Connecticut. The Science of the Total Environment 279, 195-205.

Sañudo-Wilhelmy, S.A., Flegal, A.R., 1992. Anthropogenic silver in the Southern California Bight : a new tracer of sewage in coastal waters. Environmental Science and Technology 26, 21472151.

Smith, G.J., Flegal, A.R., 1993. Silver in San Francisco Bay estuarine waters. Estuaries 16, 547-558.

Squire, S., Scelfo, G.M., Revenaugh, J., Flegal, A.R., 2002. Decadal trends of silver and lead contamination in San Francisco Bay surface waters. Environmental Science and Technology 36, 2379-2376.

Stephenson, M.D., Leonard, G.H., 1994. Evidence for the decline of silver and lead and the increase of copper from 1977 to 1990 in the coastal marine waters of California. Marine Pollution Bulletin 28, 148-153.

Webb, N.A., Wood, C.M., 1998. Physiological analysis of the stress response associated with acute silver nitrate exposure in freshwater rainbow trout (Oncorhynchus mykiss). Environmental Toxicology and Chemistry 17 (4), 579-588. 


\section{Tables}

Table 1 - Quality control performance with CRMs and various samples from the RNO. The detection limit of the method was $0.02 \mu \mathrm{g} \mathrm{g}^{-1}$ dry weight.

\begin{tabular}{|c|c|c|c|c|c|}
\hline \multirow[b]{2}{*}{ sample } & \multirow[b]{2}{*}{ origin } & \multirow[b]{2}{*}{ matrix } & \multirow[t]{2}{*}{$\begin{array}{l}\text { Certified value } \\
\text { ( } \mu \mathrm{g} \mathrm{g}^{-1} \text { d.w.) }\end{array}$} & \multicolumn{2}{|c|}{$\begin{array}{l}\text { Obtained value } \\
\text { ( } \mu \mathrm{g} \mathrm{g}^{-1} \text { d.w.) }\end{array}$} \\
\hline & & & & $\mathrm{HNO}_{3}$ & $\mathrm{HCl} / \mathrm{HNO}_{3}$ \\
\hline CRM TORT-2 & NRCC & $\begin{array}{c}\text { Lobster } \\
\text { hepatopancreas }\end{array}$ & $6.98 \pm 0.33$ & $7.0 \pm 0.4$ & $7.4 \pm 0.4$ \\
\hline CRM DOLT-2 & NRCC & Fish liver & $0.608 \pm 0.032$ & $0.59 \pm 0.03$ & $0.62 \pm 0.03$ \\
\hline SRM 1566b & NIST & Oyster tissue & $0.666 \pm 0.009$ & $0.64 \pm 0.03$ & $0.66 \pm 0.03$ \\
\hline RNO 03-124 & & $"$ & & $1.59 \pm 0.08$ & $1.60 \pm 0.08$ \\
\hline RNO 03-153 & & $"$ & & $43 \pm 2$ & $57 \pm 3$ \\
\hline RNO 03-115 & & Mussel tissue & & $0.05 \pm 0.01$ & $0.05 \pm 0.01$ \\
\hline RNO 03-109 & & $"$ & & $4.5 \pm 0.2$ & $7.5 \pm 0.4$ \\
\hline
\end{tabular}




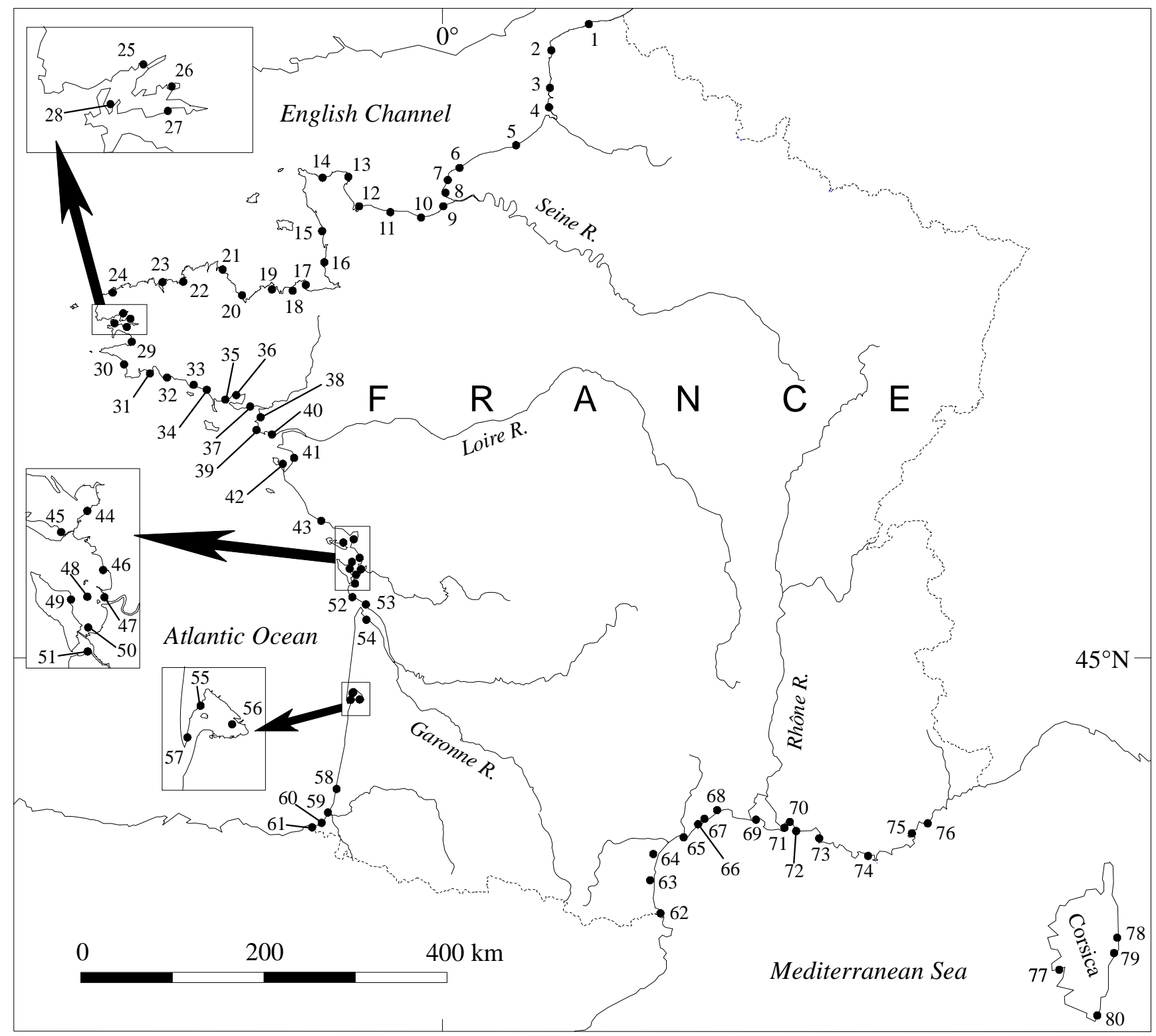

Figure 1 - Locations of the sampling sites. 


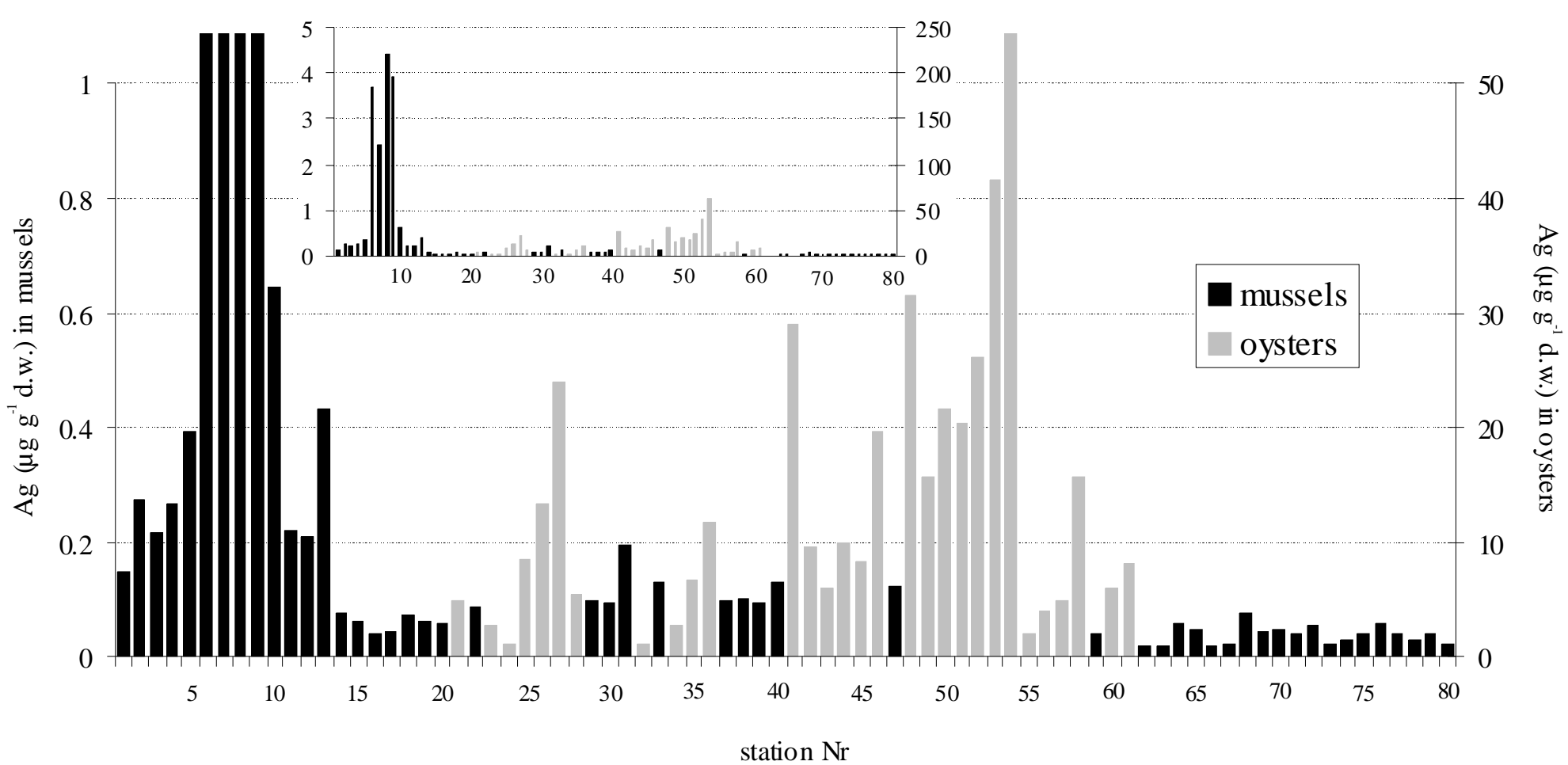

Figure 2 - Distribution of silver ( $\mu \mathrm{g} \mathrm{g}^{-1}$ dry weight) in mussels and oysters along the French coasts in 2003 - 2004 . The insert refers to a full scale for silver concentrations. 